Jurnal Kesehatan Hesti Wira Sakti

ISSN 2302-4283 (print)

ISSN 2580-9571 (online)

Online di https://jurnal.poltekkes-soepraoen.ac.id

\title{
PERILAKU REMAJA TENTANG PENERAPAN PENCEGAHAN COVID-19
}

\author{
Yusfia Ari Azizah ${ }^{1}$ \\ ${ }^{1}$ Klinik Dokter Esthi, Karangploso, Kabupaten Malang \\ (Korespondensi: yusfiaariazizah05@gmail.com)
}

\begin{abstract}
ABSTRAK
Pendahuluan: Kurangnya penerapan perilaku terhadap protokol kesehatan yang dilakukan pengunjung remaja di kafe berdampak pada peningkatan penyebaran dan mempercepat penularan Covid-19 dari kluster kafe. Tujuan penelitian untuk mengetahui perilaku remaja tentang penerapan pencegahan Covid-19 di Bangbros Coffe Rampal Kota Malang. Metode: Penelitian ini menggunakan rancangan deskriptif kuantitatif. Populasinya adalah seluruh remaja sejumlah 118 remaja. Teknik sampling menggunakan purposive sampling berdasarkan kriteria inklusi didapatkan sampel sejumlah 73 remaja. Variabel penelitian yaitu perilaku remaja tentang penerapan pencegahan Covid-19. Instrumen penelitian menggunakan kuisioner, data yang sudah didapat dianalisis dengan analisis univariat distribusi frekuensi. Hasil: Hasil penelitian menunjukkan sebagian kecil remaja berperilaku baik 14 remaja (19\%), hampir setengahnya remaja berperilaku cukup 32 remaja (44\%), dan hampir setengahnya remaja berperilaku kurang 27 remaja (37\%). Kesimpulan: Hampir seluruh penerapan pencegahan Covid-19 remaja masih dalam kategori cukup dan kurang sehingga diharapkan remaja meningkatkan motivasinya untuk aktif mencari informasi pencegahan Covid-19 dan lebih mendukung kegiatan program pemerintah dalam meningkatkan kepatuhan protokol pencegahan Covid-19.
\end{abstract}

Kata kunci: perilaku remaja, penerapan pencegahan Covid-19

\begin{abstract}
Introduction: The lack of implementation of behavior to health protocols carried out by teenage visitors at cafe has an impact on increasing the spread and accelerating the transmission of Covid-19 from cafe cluster. The purpose of the study was to determine the level of adolescent behavior regarding the implementation of Covid-19 prevention at Bangbros Coffe Rampal, Malang City. Methods: The research design used a quantitative descriptive design. The population was 118 teenagers. The sampling technique used purposive sampling based on the inclusion criteria, a sample of 73 adolescents was obtained. The research variable was adolescent behavior regarding the implementation of Covid-19 prevention. The research instrument used a questionnaire, the data that had been obtained were analyzed by percentage univariate analysis. Results: From the results of the study, a small proportion of teenagers behaved well 14 teenagers (19\%), almost half of them behaved fairly 32 teenagers (44\%) and almost half of teenagers behaved less 27 teenagers (37\%). Conclusion: Almost all of the implementation of the prevention of Covid-19 for teenagers was still in the sufficient and insufficient category, so it is hoped that teenagers will increase their motivation to actively seek information on preventing Covid-19 and support government program activities in increasing compliance with the Covid-19 prevention protocol.
\end{abstract}

Keywords: adolescent behavior, implementation of Covid-19 prevention 


\section{PENDAHULUAN}

Covid-19 merupakan penyakit yang menjadi masalah global di lingkungan masyarakat saat ini. Covid-19 merupakan penyakit menular yang disebabkan oleh jenis corona virus yang baru ditemukan (WHO, 2020). Untuk mencegah penularan dan penyebaran Covid-19, diperlukan protokol kesehatan yang harus dipatuhi oleh semua masyarakat seperti memakai masker, jaga jarak dan mencuci tangan sesudah dan sebelum berkontak langsung dengan semua orang. Namun sampai saat ini masih terlihat remaja yang sering berkumpul di kafe dan tidak menerapkan perilaku pencegahan Covid-19 dengan tidak mematuhi protokol kesehatan seperti jaga jarak, penggunaan masker, mencuci tangan sebelum dan sesudah kontak dengan teman yang lain. Perilaku remaja yang tidak sesuai dengan protokol pencegahan penularan Covid-19 dapat menyebabkan peningkatan angka kejadian penyakit dan resiko penularan Covid-19 yang lebih tinggi dan sulitnya untuk memutus mata rantai penyebaran Covid-19 (Sukesih, 2020).

Berdasarkan data dari Organisasi Kesehatan Dunia (WHO) pada 18 Juli 2020, jumlah kasus virus corona di Dunia sebanyak 260.000 jiwa dengan angka kematian 7.360 jiwa dalam 24 jam (WHO,
2020). Pada tanggal 16 Desember 2020 Indonesia memiliki total kasus 636.154 kasus, sembuh521.984 orang, dan meninggal 19.248 orang (Kemenkes RI, 2020).Di Indonesia kasus remaja yang terpapar Covid-19 sejak tanggal 28 April 2020 sampai 22 September 2020 adalah $57,67 \%$, pasien dirawat $19,29 \%$, sembuh $17,92 \%$, meninggal 2,77\% (Kompas, 2020). Pada tanggal 15 Desember 2020, Jawa Timur memiliki total kasus 72.124 kasus, sembuh 62.277 orang, meninggal 5.016 orang (Pemprov Jatim, 2020). Di Kota Malang jumlah kasus Covid-19 pada 13 Desember 2020 yang positif sebanyak 2.648 orang, meninggal sebanyak 259 orang, dan sembuh 2.214 orang (Humas Pemkot Malang, 2020).

Berdasarkan studi pendahuluan dengan cara pengamatan yang telah dilakukan di Bangbros Coffee Rampal Kota Malang pada tanggal 12 Desember 2020, pukul 18.15 WIB didapatkan masih banyak remaja yang tidak menggunakan masker. Terdapat 26 orang remaja yang berkunjung ke kafe saat itu hanya 5 remaja yang menggunakan masker dan 21 anak remaja lainnya tidak menggunakan masker, serta seluruhnya tidak menjaga jarak. Alasan para remaja tidak menggunakan masker adalah karena merasa risih jika berbicara dengan teman harus menggunakan masker dan remaja 
juga sering merasa pengap jika harus memakai masker terus menerus, remaja juga tidak menjaga jarak karena menurut remaja jika ke kafe tidak berkumpul dengan teman-temannya dan harus berjauhan rasanya tidak seru dan pemilik kafe hanya menyediakan satu tempat cuci tangan karena ketidaktersediaan ruang untuk tempat mencuci tangan. Menurut BNPB (2020) sejak tanggal 06 Agustus 2020 sampai dengan tanggal 07 Oktober 2020 angka kepatuhan masyarakat terhadap protokol kesehatan sebanyak 95\% sudah mengetahui tentang pentingnya protokol kesehatan seperti menggunakan masker, namun angka kepatuhannya masih di bawah 50\% (BNPB, 2020).

Dari latar belakang diatas peneliti tertarik untuk melakukan penelitian tentang "Gambaran Perilaku Remaja tentang Penerapan pencegahan Covid-19 di Bangbros Coffee Rampal Kota Malang".

\section{METODE PENELITIAN}

Desain penelitian yang digunakan dalam penelitian ini adalah deskriptif. Populasi penelitian adalah seluruh remaja yang berkunjung di Bangbros Coffee saat dilakukan penelitian pada 19-26 Januari 2021 jam 17.00-19.00 WIB sejumlah 118 remaja. Sampel diambil secara purposive sampling dengan kriteria inklusi remaja laki-laki dan berusia 12-19 tahun sejumlah
73 remaja. Variabel dalam penelitian ini yaitu perilaku remaja tentang penerapan pencegahan Covid-19. Data diambil dengan kuesioner yang berisi 30 butir pernyataan (15 pernyataan positif dan 15 pernyataan negatif) dengan pilihan jawaban selalu, sering, jarang dan tidak pernah. Pernyataan meliputi indikator cuci tangan (5 pernyataan), penggunaan masker (5 pernyataan), menjaga jarak/phsycal distancing (4 pernyataan), saat tiba dirumah setelah berpergian segera mandi dan berganti pakaian (4 pernyataan), meningkatkan daya tahan tubuh (4 pernyataan), meningkatkan kesehatasn jiwa dan psikososial emosi (4 pernyataan), dan etika batuk dan bersin (4 pernyataan). Skor untuk jawaban pernyataan positif yaitu selalu 3, sering 2, jarang 1, tidak pernah 0 dan skor untuk jawaban pernyataan negatif yaitu selalu 0 , sering 1 , jarang 2, tidak pernah 3. Sehingga untuk 30 pernyataan, skor terendah adalah 0 dan skor tertinggi adalah 90. Hasil perilaku dikategorikan menjadi baik (76-100\% dari total skor), cukup (56-75\% dari total skor, dan kurang $(<56 \%$ dari total skor). Responden diberikan inform consent sebelum penelitian dilakukan. Analisis data menggunakan analisis univariat. Data disajikan dalam distribusi frekuensi dengan bantuan SPSS 22.0. 
HASIL PENELITIAN

Tabel 1. Karakteristik Responden

\begin{tabular}{|c|c|c|}
\hline Data Umum & $\mathbf{n}$ & $\%$ \\
\hline \multicolumn{3}{|l|}{ Usia } \\
\hline 12-16 tahun (RemajaAwal) & 1 & $1 \%$ \\
\hline 17-25 tahun (Remaja Akhir) & 72 & $99 \%$ \\
\hline \multicolumn{3}{|l|}{ Pekerjaan } \\
\hline Bekerja & 48 & $66 \%$ \\
\hline Tidak bekerja & 25 & $34 \%$ \\
\hline \multicolumn{3}{|l|}{ Pendidikan } \\
\hline SD & 7 & $10 \%$ \\
\hline SMP & 3 & $4 \%$ \\
\hline SMA & 41 & $56 \%$ \\
\hline PT & 22 & $30 \%$ \\
\hline \multicolumn{3}{|l|}{ Penghasilan } \\
\hline $\begin{array}{l}<\mathrm{Rp} 3.018 .053 \quad \text { (menengah } \\
\text { ke bawah) }\end{array}$ & 38 & $52 \%$ \\
\hline $\begin{array}{l}\geq \mathrm{Rp} 3.018 .053 \text { (menengah- } \\
\text { menengah ke atas) }\end{array}$ & 35 & $48 \%$ \\
\hline \multicolumn{3}{|l|}{ Percaya Adanya Covid-19 } \\
\hline Ya & 63 & $86 \%$ \\
\hline Tidak & 10 & $14 \%$ \\
\hline \multicolumn{3}{|c|}{ Sering tidaknya pergi ke Coffe } \\
\hline Ya & 55 & $75 \%$ \\
\hline Tidak & 18 & $25 \%$ \\
\hline \multicolumn{3}{|c|}{ Pernah Tidaknya Mendapat Informasi } \\
\hline Covid-19 & & \\
\hline Pernah & 73 & $100 \%$ \\
\hline Tidak pernah & 0 & $0 \%$ \\
\hline Total & 73 & $100 \%$ \\
\hline
\end{tabular}

Hasil penelitian menunjukkan bahwa hampir seluruh remaja pengunjung Coffe Bangbros berusia 17-25 tahun (remaja akhir) yaitu 72 responden (99\%), sebagian besar remaja pengunjung Bangbros Coffe berpendidikan SMA yaitu 41 responden (56\%), sebagian besar remaja bekerja yaitu 48 responden (66\%), hampir setengahnya berpenghasilan $<2.700 .000$ (menengah kebawah) yaitu 35 responden (48\%), hampir seluruh remaja sering berkunjung ke kafe yaitu 55 responden (75\%), hampir seluruhnya percaya dengan Covid-19 yaitu 63 responden (86\%), seluruhnya yaitu 73 responden pernah mendapatkan informasi tentang Covid-19 (100\%), dan hampir setengahnya mendapat informasi Covid-19 dari televisi yaitu 30 responden (42\%) (Tabel 1).

Perilaku remaja pengunjung Bangbros Coffe dalam pencegahan Covid19 sebagian kecil masuk dalam kategori baik yaitu 14 remaja (19\%), hampir setengahnya masuk dalam kategori cukup yaitu 32 remaja (44\%), dan kategori kurang yaitu 27 remaja (37\%) (Tabel 2).

Tabel 2. Perilaku Ibu tentang Pencegahan Covid-19 pada Anak Usia Sekolah Dasar

\begin{tabular}{lcc}
\hline \multicolumn{1}{c}{ Kategori } & n & \% \\
\hline Baik & 14 & $19 \%$ \\
Cukup & 32 & $44 \%$ \\
Kurang & 27 & $37 \%$ \\
\hline Total & $\mathbf{7 3}$ & $\mathbf{1 0 0 \%}$ \\
\hline
\end{tabular}

\section{PEMBAHASAN}

Dari hasil penelitian yang dilakukan di Bangbros Coffe Rampal Kota Malang dengan jumlah responden 73 responden mengenai perilaku remaja tentang penerapan pencegahan Covid-19 diperoleh data bahwa perilaku remaja pengunjung Bangbros Coffe hampir setengahnya kategori cukup yaitu 32 remaja (44\%), dan kategori kurang yaitu 27 remaja (37\%). Menurut Sarwono (2011), usia adalah faktor terpenting dalam menentukan perilaku individu, sehingga 
dalam keadaan diatas responden akan cenderung mempunyai perilaku yang positif dibandingkan umur yang dibawahnya. Menurut peneliti dengan data yang diperoleh saat penelitian sesuai dengan teori bahwa pada usia 17-25 tahun sudah mulai masuk usia orang dewasa mempunyai perilaku yang positif dibandingkan umur yang dibawahnya.

Berdasarkan hasil pengamatan penelitian yang dilakukan di Bangbros Coffe Rampal Kota Malang hampir setengahnya pengunjung yang berpendidikan SMA sebanyak 18 remaja (44\%) dengan perilaku cukup. Menurut Notoatmodjo (2010), pendidikan mempengaruhi perilaku manusia, beliau juga mengatakan bahwa apabila penerimaan perilaku baru didasari oleh pengetahuan, kesadaran, sikap positif maka perilaku tersebut akan bersifat langgeng. Menurut peneliti semakin tinggi tingkat pendidikan seseorang maka semakin tepat dalam menentukan perilaku serta semakin cepat pula untuk mencapai tujuan meningkatkan derajat kesehatan.

Berdasarkan hasil penelitian yang dilakukan di Bangbros Coffe Rampal Kota Malang setengahnya responden bekerja yaitu sebanyak 24 responden (50\%). Menurut Nursalam (2011) pekerjaan umumnya merupakan kegiatan yang menyita waktu dan kadang cenderung menyebabkan seseorang lupa akan 68 | Vol. 9 No. 2, Oktober 2021 kepentingan kesehatan diri. Menurut peneliti bahwa pekerjaan dapat mempengaruhi perilaku seseorang karena ketika orang tersebut sibuk bekerja mereka lupa akan kepentingan kesahatannya.

Berdasarkan hasil penelitian yang dilakukan di Bangbros Coffe Rampal Kota Malang hampir setengahnya percaya adanya Covid-19 yaitu 30 remaja (48\%). Menurut Azwar (2013) menyatakan bahwa kepercayaan adalah komponen kognitif dari faktor sosio-psikologi. Kepercayaan disini tidak ada hubungannya dengan halhal yang gaib, tetapi hanyalah keyakinan bahwa sesuatu itu benar atau salah. Menurut peneliti kepercayaan mempengaruhi perilaku manusia karena kepercayaan adalah keyakinan bahwa sesuatu itu benar, atau salah, atas dasar bukti, sugesti otoritas, dan pengalaman.

Berdasarkan hasil penelitian yang dilakukan di Bangbros Coffe Rampal Kota Malang hampir setengahnya mendapatkan sumber informasi Covid-19 dari televisi yaitu 12 remaja (40\%). Menurut Notoatmodtjo (2012), informasi yang diperoleh merupakan faktor yang sangat berperan dalam menginterpretasikan stimulus yang diperoleh. Menurut peneliti bahwa adanya pemberian informasi Covid19 Secara berkala dapat menerima peningkatan penerapan protokol kesehatan. 
Kaum remaja menjadi kelompok masyarakat sipil yang memiliki jangkauan luas dan sumber daya potensial untuk mendorong kebijakan efektif dalam memastikan penerapan pencegahan Covid19 di lingkungannya. Sedangkan kafe merupakan tempat yang sering digunakan para anak remaja sebagai tempat berkumpul maupun sekedar bersantai untuk melepas lelah sehabis beraktivitas. Maka dari itu para remaja harus mengerti pencegahan Covid-19 sesuai dengan protokol kesehatan seperti memakai masker jika keluar rumah maupun di keramaian, jaga jarak dengan sesama rekan, dan sering mencuci tangan sebelum dan setelah berkontak langsung dengan sesama rekan. Para remaja harus tahu mengenai penerapan pencegahan Covid-19 supaya bisa memahami dan mengerti begitu cepat penularan Covid-19 dan pentingnya mematuhi protokol kesehatan untuk memutus mata rantai penyebaran Covid-19 (Nurislaminingsih, 2020)

Karena dampak dari tidak menerapkan perilaku pencegahan Covid19 bisa mengakibatkan kerentanan sosial pada remaja seperti akibat lockdown remaja menjadi merasa bosan melakukan aktivitas di dalam rumah, sekolah di rumah, dan tidak bisa berkumpul dengan temannya. Sehingga masalah kerentanan sosial remaja harus mendapat perhatian yang serius. Hal ini dikarenakan kerentanan sosial pada remaja dapat berdampak negatif bagi dirinya sendiri maupun orang lain. Dampak kerentanan sosial dapat membuat remaja melakukan tindakan apatis, tindakan irasional, dan tindakan kriminal dimasa pandemi (Musyirifin, 2020).

Salah satu cara meningkatkan perilaku remaja dalam menerapkan pencegahan Covid-19 adalah dengan memberi gambaran kepada remaja dan pemilik kafe supaya paham tentang perilaku penerapan pencegahan Covid-19 dan mengetahui berbagai sumber informasi lebih lanjut mengenai bahaya Covid-19. Sehingga timbul kesadaran bagi remaja untuk mematuhi protokol kesehatan dan pemilik kafe untuk mewajibkan pengunjung memakai masker, menyediakan tempat cuci tangan, mengurangi tempat duduk pengunjung atau jaga jarak, dan membatasi jumlah pengunjung (Risma, 2020)

\section{KESIMPULAN}

Berdasarkan hasil penelitian yang dilakukan di Bangbros Coffe Rampal Kota Malang, didapatkan kesimpulan bahwa hampir setengahnya perilaku remaja dalam pencegahan Covid-19 masuk dalam kategori cukup sebanyak 31 remaja (44\%), dan dalam kategori kurang yaitu 27 remaja 
(37\%), serta sebagian kecil perilaku remaja dalam kategori baik yaitu 14 remaja (19\%). Dari hasil penelitian diharapkan remaja meningkatkan motivasi untuk aktif mencari informasi pencegahan Covid-19 dan lebih mendukung kegiatan program pemerintah dalam meningkatkan kepatuhan protokol pencegahan Covid-19.

\section{DAFTAR PUSTAKA}

BNPB. 2020. Tingkat kepatuhan masyarakat terhadap protokol kesehatan.https://www.inews.id/ne ws/nasional/bnpb-tingkat-kepa tuhan-masyarakat-terapkanprotokol-kesehatan-berbeda-beda

Kemenkes.2020.

Kesiapsiagaan mengahdapi infeksi Covid-19. Jakarta:https://www.kemkes.go.id/ index.php

Kemensos. 2020. Perilaku hidup bersih dan sehat (PHBS).Jakarta. Kemensos RI

Kompas. 2020. Rincian usia Covid-19 di Indonesia.https://www. kom pas.com/tren/read/2020/04/29/1217 00365/9.511-positif-virus-coronaini-rincian-usia-pasien-covd-19-diindonesia-?page $=$ all

Musyrifin. 2020. Strategi Pengendalian Kerentanan Sosial Remaja Berbasis Bimbingan Pribadi Sosial. Prosiding Seminar Nasional Bimbingan dan Konseling Mengukuhkan Eksistensi Peran BK Pasca Pandemi Covid-19 di Berbagai Setting Pendidikan Universitas Negeri Malang 6 (272275)

Notoatmodjo. 2010. Ilmu perilaku kesehatan. Jakarta : Rineka Cipta.
Notoatmodjo. 2012. Metodologi penelitian kesehatan. Jakarta : Rineka Cipta

Notoatmodjo. 2014. Promosi kesehatan dan perilaku kesehatan. Jakarta: Rineka Cipta.

Nurislaminingsih. (2020). Layanan pengetahuan tentang Covid-19 di lembaga informasi.

Pemkot, H. 2020. Pasien positif Covid-19 kota Malang. Malang.

Pemprov Jatim.2020. Kasus Covid-19 Jawa Timur. Surabaya : https://www.google.com/search?cli ent=firefox-b-

$\mathrm{d} \& \mathrm{q}=$ kasus+covid+pem prov+jatim

Risma. 2020. Rencana pencegahan dan pengendalian Covid-19.

Sinaga. 2017. Teori dan Aplikasi Pendidikan. Yayasan Kita Menulis.

Siyoto. 2015. Dasar Metodologi Penelitian. Sleman: Literasi Media Publishing.

Sukesih, Usman, Budi S., Sari D.N.A. 2020. Pengetahuan dan sikap mahasiswa kesehatan tentang pencegahan Covid-19 di Indonesia. Jurnal Ilmu Keperawatan dan Kebidanan 11 (2:258-264).

WHO. (2020). A commentary on "World Health Organization declares globalemergency.www.who.int/ind onesia/news/novelcoronaviru s/qafor-public.

WHO. (2020). Anjuran penggunaan Maker dalam konteks Covid-19

WHO. (2020). Virus corona: Angka kematian akibat pandemi Covid19.https://www.bbc.com/indonesia/ dunia-53460946

William H.Ukers.2012. All about Coffe.: Adams Media 
Yusuf. (2017). psikologi perkembangan

REMAJA ROSDAKARYA. anak dan remaja. Bandung: PT 